\title{
A Systematic Review Of The Impact Of Performance Appraisal Systems And Competency Management Framework On The Performance of Employees In The Telecom Sector
}

\author{
Uttam Sahay, Dr. Gagandeep Kaur \\ Associate Professor, University School of Business, Chandigarh University.
}

\section{ABSTRACT}

Among themost efficient employee related management practices identified in both the developed and the developing nations is performance appraisal system, which is also recognized as a strong motivator for employees. It also enables smooth functioning of managerial decision making, administrative decision making and the employee development. The present study reviews prominent and key studies conducted in recent past systematically in order to assess how organizational performance appraisal systems and competency management frameworks affect employees' work performance in the telecomsector.

Keywords

performance appraisal, telecom sector, competency management framework, employee performance, work performance Article Received: 18 October 2020, Revised: 3 November 2020, Accepted: 24 December 2020

\section{Introduction}

In the present business environment which is dominated by market competition, businesses are using performance appraisal as the tactical method to assimilate human resource accomplishments with corporatestrategies in order to develop competency in employees, enhance their performance, and distribute rewards (Ademola, 2017). (Khan et al,2018) mentioned that fairness is imperative in a performance management and appraisal system. It is important that the process is fair and accurate in the letter and spirit and a reliable and just performance rating system is essential. Performance appraisal systems help to assess employee behavior, determine critical challenges and encourage agile solutions. This assessment works as an important tool for the supervisor to recognize, evaluate and improve an individual performanceat workplace. This identification can encompass various practices such as recognition of the employee's strengths and weakness, their career development and job satisfaction. (Balu, 2006) defined performance appraisal as the recognized and systematic instrument used in finding, analyzing and recordevidences in relation to the employee who is being assessed. The construct of performance appraisal system should be linked with explicitfeatures of job performance. This is required to establish a connectedness between employee's characteristics and productivity and efficiency on the workperformed.

In order to define performance superiority in an organization, a competency development and management outline is developed. This framework generally involves huge number of competencies that are used to the different job-related roles within an organization. The competencies developed describes the excellence in the working behavior and work towards establishing benchmarks against which the employees are assessed(Jayan, 2006).This competency framework works as the tool which helps to communicate which behavior is desired, appreciated, accepted and gets rewarded within the organization with for a specific role, to ensure 
that employees have a common and uniform knowledge of the organization's values and their likely roles (IAEA, 2016). (Boyatzis, 2008) defined competencies as primaryfeature of anindividual that may be a motivation, attribute, dexterity, self-image, role in a society, or a sum of understanding and acquaintances one uses. These features are learnt in noticeable and distinguishable patterns of conduct, related to performance at work andcommonly include knowledge, skill and abilities (KSA). The telecom competency framework generally includes the core values and the core functional competencies(Chineduet al., 2016). Behavioral and functional competencies are an important part of the present-day business because through this staff gets a properknowledge of the conduct at work to be exhibited and the level of performance that is required toattainorganizational goals. The competency framework facilitates to successfully align employee's skills, abilities and their awareness with the organizational urgencies and deriving industrial betterment and effectiveness(Rost, 2014). In the telecom sector competency framework is applied in three different stages that is at planning stage, talent acquisition stage, managing employee performance and employee development stage. In the planning stage these are applied with the job design, basically involving to determine the job content, the requirements in order to bring out the work and specification of connection between the job holder and the other employees(Tripathi and Agarwal, 2014). In the recruitment stage, the assessment of competencies form an important part of the hiring process. The competencies at this stage helps in assessment of the candidates who are appropriate for the given job. While in managing employee performance and the employee development stage, competencies play a significant role in the establishing the standards against which the employee performance will be measured(Abram and Anderson, 2014). However, there are still various Indian organizations that prefer the conventional techniques of performance appraisal in the place of the modern appraisal methods. There are various techniques that firms uses in order to evaluate their employee performance most important are graphic rating scales, critical incident method,ranking method, and narrative essays, forced distribution method (Bell Curve), check list method, confidential report system. Some of the modern appraisal methods are Management by Objectives (MBO), Behaviorally Anchored Rating Scales (BARS), Human Resource Accounting (HRA), and Assessment Centers and 360 Degree Feedback.Out of all traditional methods, the Bell Curveis widely used method. The method is about two decade old and most of the big organizations started using the bell curve method of performance appraisal in the later part of ' $90 \mathrm{~s}$. The method is widely used by large organizations in India such as ICICI Bank,Infosys and Aditya Birla Group (Bhattacharya and Roy, 2014). According to Indian times, more than $80 \%$ of companies in India use the normal distribution curve or bell curve shaped performance appraisal method to evaluate and relatively rank their employeeskeeping in view of their individual performance into five different categories such as Far above Expectations, Above Expectations, Meets Expectations, Lower than Expectations and Far lower than expectations in a forced distribution ranking order. An employee getting a rating of Far exceed expectation is considered top ranked employees are considered "high performing and high potential" and mostly rewarded and retained by the management for higher roles and are put through leadership development programs. The appraisal system based on forced rankings system helps the manager to compare employees' relative performance with other employees and put team members as per the distribution/bell curve(Patel,2019).

The proponents ofthis traditional system of annual appraisal suggest that till a better system is developed, the forced ranking system based on normal distribution curve (bell curve) method is a more foreseeable,dependable and maintains a 
equilibrium of being fair and instill trust between all the stakeholders.

The prime objective of the study is to access the impact of performance appraisal system and the competency management framework on the work performance of the employees in the telecom sector.

\section{Literature review}

\section{a) Importance and significance of performance appraisal systems}

In an organizational context employee motivation has great significance due to its ability to manage and manipulate human behavior, i.e. Todirect, channelize and sustain that behavior as desired. In this respect appraising employees' performance can be used to encourage the employees. In the course of performance appraisal/ assessment, the employer or the evaluator offers performance feedback to the employee (also called as "performance number"), this is generally used by the management to determine the reward as the part of the motivation process(Pulakos, 2012). Thus, at the time ofjobvacancyin the organization beyond the entry level these feedbacks and performance number becomes an important and credible source of information for the managers to take decisions and use them in the internal promotions. It is also important to note that such recognition through giving higher jobs in organizational hierarchy not only serve a huge motivation factor for the individual simultaneously it also creates differentiation at work place and plays a significant role by sending messages to fellow colleagues that sincere and hard work surely be rewarded(Idowu,2017).

Performance appraisal also proves to be useful in motivating employees by providing them with a platform for recognition(Pulakos, 2004). The performance appraisal in thiscontext involves personal non-monetary award by giving them praises in the form of compliments, certificates of achievements, ceremonies like public celebrations and speeches, which helps in reinforcing the desired behavior. The performance appraisal systems in this form tend to trigger innovativeness in employees and encourage behavior that leads to better performance (Selvarajanand Cloninger,2014).

Further performance appraisal is also important in identifying an employee's strengths, thus helping to capitalize on them. Similarly, weaknesses are also identified so that effective control measures are put in place to help employees improve on their shortcomings (Connor, 2016). Moreover, they help employees reflect on past performance to set benchmarks for improving their future performance. Thus, the feedback given in the performance appraisal process confirms that the employers' expectations are informed in a very clear way(Karen, 2013). Here the feedback provided can significantly led to the improvement in the employee morale and motivation by mentioning the area in which they performed exceptionally well. Further in the case when the performance of an employee was below an expected level, fair feedback on how to improve can help the employees to course correct the insufficiencies and the disappointments thus reinforcing changed and appropriate behavior (Shternet al., 2015). Outcomes of performance appraisal in form of financialrewards act as an important tool to motivate an employee by satisfying his needs through the means of incentives and increments. This extrinsic motivation enables the employees in the organization to work harder and putadditional effort thus impacting their performance at work(Oshri and Ravishankar,2014).

\section{b) Importance and significance of competency managementframework}

Adopting a competency-centered framework by organization is a widely popular phenomena in the business world since it works towards providing importance in various work environments, cultures, businesses and across the multiple career and talent management practices(Jaim, Yasar and Unal, 2013). Based on this goal, the competency 
management framework provides certain other advantages as well. First is that it leads to talent acquisition, since the organizations or the firms that follow the competency based management framework are better able to manage their talent acquisition process effectively, especially when it comes to manning the important positions swiftly and meritoriously since they had the skill sets and competencies defined pre- hand which makes the process simpler(Sharma, 2014; Balaji and Vimala, 2012). Also, when a firm or the business has holistically defined success profile, it is in a better position to hire the talent required. Moreover, when these critically defined competencies are targeted in interview and assessment, they enables new talent to better prepare to meet the business needs, thus reducing the ramp up time (Development Dimensions International, 2015).(Benayoune, 2017) stated that the competency-based management framework provides a platform for building development plans and enables mangers to provide feedback through that platform. Since at the organizational level, when the explicit behaviors and skills are evidently identified and defined, the development plans can be more effectively planned and communicated. He further stated that competencybased framework provides a clear view to the top management since they build talent pipeline in order to get right candidate to meet the business requirements (Waqas, Chughtai and Latif, 2015). Since this framework provides the standards against which the individual can be assessed, the intelligence that comes with assessment helps an organization to detect talent gaps before these deficits become apparent and negatively impact the business. (Tripathi and Agrawal, 2014) mentioned that leveraging the competency framework helps managers and employees to create a common language for mapping their performance plans. On the other hand, organizations without competency frameworks tend to rely too much on WHATs without having the required behavioral guidance. The competency helps in developing the performance plan so that the employees in the organization understand the specific behavior that is required in order to achieve the target results. (KPMG, 2014) mentioned in their report that business by developing the critical competencies can establish more strategic career planning systems in their organizations. This can help employees by providing them with the platform that can provide them with the future focused development thus preparing them for their next move. Thus, mangers through this competency framework need to reinforce the behavior among the employees which is in tune with the desired outcomes and beliefs of the organization(Velnampy, 2006).Organizations have traditionally been dependent upon financial methods or statistical numbers to judge their performance, worth and strength. The often quoted "soft", employee focused methods such as employee outlooks, qualities and views are now being accepted as essential forecasters of employee conduct and performance at work(John, 2013). An employee may have differential impact from different attributes at workplace, but their attitude, behavior and skill create an important part in their performance. In the 21 st century, few among the most important contemporary issues in the study of organizational behavior is the impact of behavioral /personal traits (competencies) on organizational performance and its success.It is appreciated that employees' job performance act as a source of distinctive and competitive edge and enhancing overall organizational effectiveness. From the organizational standpoint, competencies are defined by two main streams: organizational or personal (Jaim, Yasar and Unal,2013).

The main components of the competency framework include values, core competencies and the leadership/managerial competencies (UNESCO, 2016). The principal values or core values are the doctrines and the principles that gives the foundation to the working of the organization and thus provides guidelines of the actions and the behaviors of the employees. Second component includes skills, attributes and 
the behaviors that are treated important and un compromising for the staff members(Chansirisia, 2012), and finally, the supervisory or managerial competencies are the skills, attributes and the behaviors, crafted and stated for the employees in response of the present responsibilities. The components of the competency framework can show with the help of the followingdiagram.

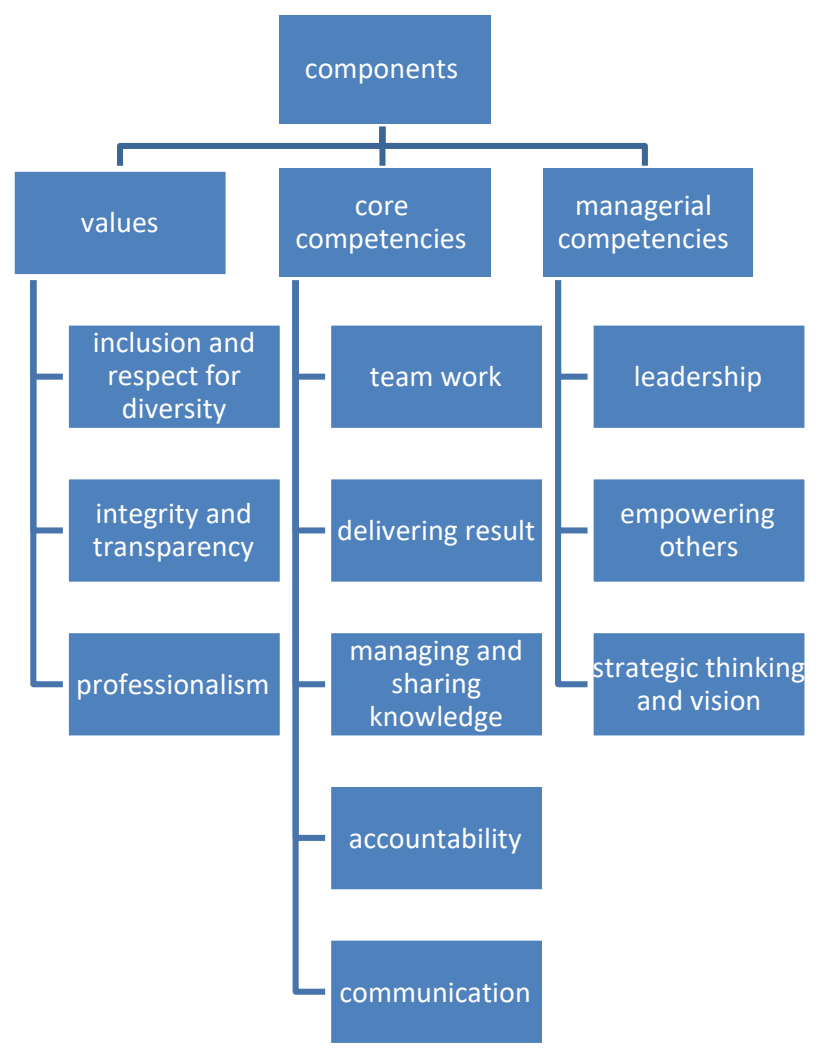

Figure 1: Components of competency framework (UNESCO, 2016)

The main components of the competency framework can be further divided under different elements like values component further incudes inclusion and admiration for diversity, integrity and transparency and professionalism. Similarly, core competencies include teamwork, delivering results, managing and sharing knowledge, accountability and communication in the organization. The third component which is the managerial competency includes leadership, empowering people in the organization and finally creating strategic thinking ability and vision among the employees (UNESCO,2016).

\section{c) Factors affecting employees' work performance}

With the presence of the volatileindustrial atmosphere and the fierce competitive rivalry ,firms are compelled to accomplishdefiniteprinciples by bettering their performance so as to jell with the huge demand and dynamics, else a lot of issues will emerge, also including the threat of businessbeingclosed(JhaandKumar,2016). Theperf ormanceof theorganizationisthesumof the performance of every individual within the organization. Thus, determining the elements that impacts the performance of an employee becomes crucial for the organization (Connor, 2016). Although there are numerouselements that impacts the performance of an employee.The main factors that will be reviewed in the following study includes organizational environment related factors, work related factors and employee related factors.

Environment related factors- organization support, learning and development culture, communication patterns, organizational climate and the ecologicalundercurrents are some of the firm's environment related factors that have a major influence on the performance of an employee. (Thao and Hwang, 2010) said that management support is a basic factor that impacts employee performance, when an employee receives the organization's support in his work, it is almost sure that the employee will show improved performance. The factor of management support also affects the employee commitment towards the organization. (Muda, Rafiki and Harahap, 2014) mentioned communication as another important factor that affects the employee performance. Communication within the organization is the act of interaction among the individual in delivering the information's. With an efficient commination framework a firm is capable to maintain a decent communication within teams and the different divisions in the organization thus enhancing the performance at 
the individual level(Ellenkampet al., 2016). Thus, it is the obligation of the supervisory to guarantee that all the information is delivered accurately in order to have accurate deliverance of the responsibilities. (Zafar, Karim and Abbas, 2017) found that the organizational climate is one of the important aspects that affects the attitude of employees' and behavior within the organization. The climate of the organization furthermore influences the employee's adaptableness towards the organizational and therefore their productivity levels. (Arshad and Kanwal, 2017) stated that the training culture in the organization impacts the knowledge and skill level of the employees thus leading to improved work performance. This acquisition of skills and knowledge in workplace helps the employees to better deal with the jobrelated challenges thus leading to better workperformance.

Job related factors- one of the major job-related factor that affects the work performance is the job autonomy. Job independence means the degree to which the allowed to make the decision regarding the way they want to perform the task or the work given to them. (Saragih, 2015)in his report mentioned that refers to the degree of the freedom given to the employee in the workplace regarding their decisions on the way they want to perform their job. It has been found that more the flexibility employees have in their job execution the more flexible they are thus leading to more commitment and the proactiveness towards the organization(Munisamy, 2013)

Employee related factors- there are various employee-related aspects that affects the employee work performance such as the adaptability, skill flexibility, motivation etc. (Clarke and Holdsworth, 2017) in their report mentioned that employees who has variety of skills can prove to be an asset for the organization, but the skill flexibility that is how employee can apply his or her skills in their jobs have major impact on employee work performance. The form can help the employee to improve their skill flexibility by various methods such as job rotations or by making them work in the cross functional teams. This process tends to create a unique skill combination that can be easily exploited by an organization and moreover they are difficult to be copied by other contenders or competitors (Aboazoum, Nimran and Musadieq, 2015)

\section{Research methodology}

The present study used the approach of systemic analysis to access the impact of performance appraisal system and the competency management framework on an employees' work performance in the telecom sector. Although there are various studies that have been conducted in this domain but almost all the studies adopted the quantitative approach. Thus, the present research paper opted for the systematic analysis that aided the researcher to identify, critique and analyze the evidences that corresponds to the issue in thehand.

\section{a) Search strategy and study selectionprocess}

The systematic review was conducted under the guide of the PRISMA application. The following application guided the researcher on the criteria based on which studies are included for the systematic review. The study has encapsulated various other studies with the objective of gathering required information in the present context. Besides this the search strategy was also opted in order to identify the approximate number of the studies that exist in this context. For this purpose, the researcher has used various data bases which included social work abstract, CINAHL complete, MEDLINE, Psyc ARTICLES, PsycINFO, Academic search complete and the Ebook collections. In addition to this the study also made use of the Google scholar in order to identify, if there are any additional studies that have been missed from the other database. However, the researcher made sure that no published dissertations or the theses are included in this search. Further the guidelines 
provided by the PRISMA along with this different terminology that relates to the present topic have been used while searching through the databases. The studies that have been included in the following paper are presented in the table 1 in the appendix at the last of the chapter. The keywords included: performance, employee, competency, framework, performance appraisals, telecom sector. The studies that reflected one or more than one of the keywords were considered within the eligibilitycriteria.

\section{b) Inclusioncriteria}

The studies included in the present research were based on following criteria:

- The researcher included the studies for which the full access and the information was available.

- Studies that have published in the Englishlanguage.

- Studies that included at least one of the keywords that was relevant according to the scope.

- Studies that have been published in the year 2013 orafter.

- Studies that focus on the relationship between performance appraisals and employee performance.

- Studies that presented works around competency framework in the telecomsector.

- Studies that showed how the competency framework affects the employeeperformance.

\section{c) Exclusioncriteria}

Keeping the objective of the study the researcher developed certain eligibility criteria in order to segregate and filter out the studies that were important from the ones that were irrelevant or did not had proper information. The exclusion criteria are presentedbelow:

- Studies for which the only the abstract and reviews were available or their restriction on reading.

- Studies that had very limited information with respect to the topic of thestudy.

- Studies that were published in the foreign language and for whom the content was not available in Englishlanguage.

- Studies that were published before the year2013.

- Studies that were from the sector other than the telecomsector.

\section{d) Studyselection}

The researcher followed a systematic process of identification and selection of studies appropriate for the present analysis. The first step included referring to various databases to identify the right studies. For this step, the researcher made use of open source as well as restricted databanks such as Google Scholar, Scopus, Web of Science, after entering the appropriate keywords, was able to identify 1883 studies that were relevant to this research. As part of the next step, covidence removed duplicate studies including studies with similar content, bringing this number down to 1121 studies. After this the researcher eliminated studies with restricted results and access, and scrutinized the abstracts carefully to ensure its relevance, reducing the number further to 661 studies. A second round of personalized screeningbrought the number of relevant studies down to 53, finally enabling the researcher to select 18 most suitable studies for this analysis.

\section{Data analysis}

This section provides a systematic review analysis of the impact of the performance appraisal and the impact of competency management framework on the work performance of the employees in the telecomsector.

\section{a) Impact of performance appraisal systems on work performance of employees in}




\section{telecomsector}

The study presented by (Ehsan, 2018)reviewed the impact of employee related management practices such as performance appraisal, work design and compensation and benefits on employee performance in the telecom companies of Pakistan. The study employed both the primary as well as the secondary approach. Primary data from 100 employees of the telecom companies were captured through a questionnaire by circulating the same to them. The data was analyzed using the correlation and the regression tools. The paper also talked about the dimensions of the performance appraisal which includes performance measures, the evaluator of the performance and the frequency and periodicity of the appraisals. Thefindings showed an affirmativeconnection between the performance appraisals, compensation and work design on employee's performance.

(Malik, Phil and Bakhtawar, 2014) dida similar work to know the how performance appraisal impacts an employee's performance, using the data captured from the employees of the Pakistan telecommunications company limited (PTCL). PTCL is the most reliable and converged telecommunication service provider in the country. The central objective of the study was to findvarious practices used to conduct performance appraisal that are used for the permanent as well as the contractual employees working together in the organization as well as the perception of the permanent and contractual employees regarding them. In order to reach to the finding the questionnaire was circulated among the 96 employees of both the groups. The result pointed out that both the groups had very different viewson the performance appraisal system. For permanent employees the system was not fair neither transparent. Thus, showed the great resentment on their prevailing appraisal process. The result suggested that the employees found this as an insignificant annual ritual that does not provided them with any benefit. On the contrary the results for contractual employees was very satisfying and were happy about the way theappraisal system was implemented.

(Ademola, 2017) conducted his study in Nigeria, with the globalization there has been a cutthroat competition in the market and especially in the telecom companies. Moreover, with the implementation of liberal policies in the telecom sector in the region of Nigeria further increased the competition in the industry. Thus, companies found performance appraisal system as a powerfultool to survivein this era of globalcompetitionand to motivate their workforce simultaneously. Thus, the study tried to findthe impact of performance appraisal system on the performance ofemployees. By using random sampling technique and use of structured questionnaire the study was conducted with 260 employees data was also collected using personal interview further mean, standard deviation and the linear regression approach were used to find the results. It was found that the employees' awareness regarding the performance appraisal system was quite high in Nigeria and also it had significant impact on their performancelevels.

(Bulto and Markos, 2013) studied the impact of performance appraisal on the motivation of employees and thus on their work performance.

To study that 200 hundred employeesof the telecom companies in Ethiopia were identified by using the stratified simple random sampling technique and were given a structured questionnaire. Further correlation and the regression techniques were usedto analyze the data. The outcome of the study confirmed the relationship between performance appraisal system and employee motivation and hence impacted their level ofperformance,

(Malik and Aslam, 2013) presented that to effectively manage employees in the organization performance appraisalsystem is generally used as an important tool. To find that a study was 
conducted in the telecom companies using 120 respondents with an objective toknow employees' perception about performance appraisal and how does the same affects their motivation levels and thus impacts their performance. The data so collected was analyzed using regression, ANOVA and the AHP model. The results pointed out that the employee had faith in the performance appraisal system which affected their motivation to perform and thus affects their performance levels. Along with this the observed fairness of the system also affects the employee's commitment and the proactiveness towards theorganization.

(Marwat, Qureshi and Ramay, 2013) presented the study that tried to discover the impact of human resource management activity such as performance appraisal on the work performance of employees in telecom sector. According to the study conducted telecom sector is experiencing a tremendous growth. Further for the telecom companies to keep up with the competition requires to attract and retain the efficient workforce. To achieve this telecom firms requires to implementeffective performance appraisal system beingthe most significant one.

In an another study conducted by (Janjua and Gulzar, 2014) to assess the impact of performance appraisal on employee retention, employee commitment towards the organization and the performance of employees in the telecom sector of India. Again, to analyze the situation questionnaire approach was adopted, where the questionnaire was circulated among 250 employees, regression and the correlationtools were usedto analyze the data. The results of the study presented thatefforts on employee retention, making employee more committed and ensuring employee performance are hugely impacted by performance appraisal systems. It was also highlighted in the study that it was the employee loyalty also impacted their performance levels.

(Arshad, Masood and Amin, 2013) analyzed the impact of policies related to performance appraisal on job satisfaction, turnover intention, work performance and loyalty towards the supervisors. According to the study companies generally modify their performance appraisal strategies based on the requirement in order to retain the efficient workforce and maintain their and loyalty towards the organization. For study data was collected from 207 white collar employees, who agreed that the performance appraisal system majorly impacted their job satisfaction, turnover retention and work performance.

(Chahal, Jyoti and Rani, 2016) conducted a study to findthe effect of the high-performance human resource management practices such as performance management, performance appraisal and compensation on the performance of employees in the telecommunication sector. The census method for the data collection was used from the employees of the telecommunication sector in Jammu and Kashmir. The study used the CFA and SEM tools to check the reliability and validity and for hypothesis testing respectively. The results pointed out that the performance appraisal system among all the human recourse management practices proved to be the mediating factor between the high-performance human resource management practicesand employee performance.

(Nadarasa, 2013)employeein any origination is considered as one of the keyresources for the organizations. The companies now and then try to add on value to their human resources for this they adopt many human resource practices. Moreover, any failure in the management of the human capital can create absolute fatal problems for an organization. Thus, the biggest challenge faced by the organizations is to engage the heart and mind of their employees for which they adopt many human recourse management practices and one of the most important technique is giving them performance appraisal. The study tried to find the effect of the performance appraisal on the 
performance of employees in the telecom sector of Jaffna district. Correlation and regression analysis were used to find the strength of relationship between the two variables. A significant relationship was established between the performance appraisal system and employee performance.

\section{b) Impact of competency management framework on work performance of employees in telecom sector}

This section analyses the impact of competency framework management on the work performance of employees. For this purpose, various studies have been reviewed which are presented as below.

The study conducted by (Martini et al., 2018) stated that competencies are strategic for the development of the organization. The study was conducted to analyze and examine the influence of the competency management framework on the work performance of the employees by taking organizational commitment as one of the mediating variable. Where the organizational commitment was described as the acceptance by an individual employee towards the goals and values of the organization and the individual who have the wish to continue in the organization . Further the organizational commitment was divided in three dimensions that included affective commitment, normative commitment and the ongoing commitment. The study included 112 respondents from Indonesia. Structural equation modelling-partial least square was used as data analysis technique. The results suggested that both employee competency and organizational commitment have positive impact on the performance of an employee. Moreover, it was also found that the various dimensions of the commitment acted as the partial intermediary in establishing the relationship between competency and employee performance.

In an another study conducted by (Prowse and Prowse, 2009) on the performance appraisal, goal setting, competency framework and the employee reaction to the performance related appraisal and to the competency framework. The study consisted of 191 respondents from the telecom sector. It was found that the performance appraisal and competency-based management directly and indirectly impacted the performance of an employee. The study also suggested that the competency framework led to more acceptance, perception and efficacy among the employees.

(Yaşar, Ünal and Zaim, 2013) presented the study that which analyzed the impact of the personal competencies on their performance at work in the telecom sector of turkey. The structured questionnaire was distributed among 3000 employees in 30 companies out of which total of 2679 completed questionnaires were returned. As statistical tool factor analysis was used. The findings established a significantly affirmative relationship between competencies and individual performance. Moreover, the core competencies have major impact on the performance of an individual. Also, it was found that managerial competencies in the organization appeared to be very important factor that affected the employee work performance in theorganization

(Kurniawan, Guswandi and Sodikin, 2018) studied the influence of the competency management framework, motivation and ability on the employee performance in the region of Jakarta. The number of the respondent included in the study were 40 who were selected on the basis of the simple random sampling method. In order to source the data, the structured questionnaire was developed that was distributed among the respondents. The findings of the data pointed out that partially all the independent variable namely competency framework, motivation and ability have impact on the employeeperformance.

(Rahmah Ismail and SyahidaZainalAbidin, 2010)themain aim of the study was to find the influence of the competency framework on the performance of an employee. The analysis was 
based on the sample of the 1136 employees who belonged to the telecom sector. The analysis of the findings showed that competency-based framework had major impact on the employee work performance. This framework led to increase in the employees'satisfaction and hence their loyalty towards theorganization.

The study conducted by (Aima, Adam and Ali, 2017) analyzed the impact of the competency and the work motivation on the employee performance. For the study, a sample of 127 employees were taken by using purposive sampling technique from the telecom sector in Jakarta,a structured questionnairewas used to collect the data. To check validity and reliability of the data the Pearson product moment and Cronbach alpha test were performed. Hypothesis were tested by using the multiple linear regression. It was found that competency framework as well as the motivation does significantly affect the employee performance in an organizational setting. Development of the employee skills according to the competencies required in the organization can significantly increase theirproductivity.

(Mahmoodet al., 2018) the paper examined the relationship between the competency that are developed through training on the job among the employees on their work performance in the organization. The data for the study was sourced through the help of the questionnaire that distributed among the respondents in Johor, Malaysia. Factor analysis approach was used to analyze the data which was coupled with the descriptive analysis, correlation analysis and the hierarchical regression analysis. It showed that the impact of training given at the workplace significantly developed the competency among the employees that positively impacted their work performance. Thesefindings can facilitate the telecom sector to priorities their competencies in order to develop employee's performance at workplace.
(Mangundjaya, Aprilianti and Poerwadi, 2014) studied as how the organization can work on improving the employee performance by the developing the required competencies among them. The authors in their paper defined competency as the map or the indication of the apt behavior on part of the employee that will be valued in the organization. Further it was identified that the organization that valued and recognized the importance of competencies and hence devoted their time as well as the money in the development of the competency witnessed significant increase in their employee performance. However, it was also deducted that competency framework along with benefits have certain drawbacks as well which includes that the assessment process reliesto much on the manger's judgment, subordinates are generally hesitated to give actual ratings, validity of instrument is sometime questionable.

(Tripathi and Agrawal, 2014) studied the competency-based framework and its importance in organizational setting while affecting the performance of employees in the organization. The following study took the employee commitment as the mediating variable. The paper further defined the competency-based management framework that affects the employee performance, the driving force behind the competency framework and its uses in the organization with the help of the existing literatures on the present topic. Due to the importance of the competency-based management system organization have been employing this technique in their talent acquisition and selection process, capability building and development process, performance management process and in talent and career development process as well.

(Lišková and Tomšík, 2013) the study deals with as to how competency framework is used in managing the human resource function in an organization and to study its impacts on the performance level of the employees. The paper focused on identifying the required competencies, 
components of competencies and their impact on the performance of employees. On basis of the earlier studies conducted on this topic, the competency-based framework was identified as an effective tool to manage the work performance. Finally, the paper also emphasized on the possibility of how can competency framework be used inmany other domains in the organization.

\section{Discussion}

The objective of the study was to access the impact of performance appraisal system and the competency management framework on the work performance of the employees in the telecom sector. For the purpose of the study various past literatures on this topics were reviewed. The findings of all the studies indicated that there exists a positive relationship between performance appraisal and competency management framework on the work performance of the employees in the telecom sector. As per the studiesfew important variables that came across through which performance appraisal impacts employees work performance and these are:

Motivation: the performance appraisal by affecting the employee's motivation level affects their work performance. When the employees find that their performance goals are clearly welldefined, their challenges to perform are recognized, and their career growth plans are in line. This impacts their motivation levels and thus inspires them to achieve their goal by improving their work performance. Thus, the management by crafting a all-inclusiveroad map for their employee's growth and providing them achievement level to endeavor for will automatically motivate the employees to have higher level ofefficiency.

Clarity: Human Resource generally do their work to the best of their capabilities based on the directionof their management and leadership. In the performance appraisal process a manager as well as the employee review the key performance indicators and compare the employee performance with respect to the set performance standards. They get the better idea and the clarity of where there are lacking and where more effort is required. Thus, directing their efforts in the right direction. This helps the firm as well as the employee to achieve better results in an effective way without wasting time as well as the resources.

Take responsibility: while preparing the annual review of the employee performance, managers generally keep the track of all the accomplishments as well the challenges the employee faced throughout the year. When these track records are presented to the employees it gives them an opportunity to benefit from their accomplishments as well as take the responsibility for the challenges. By making the employees claiming their ownership of their performance issues, it generates the sense of commitment towards the organization, this positively impact their performance levelpositively.

Teamwork: performance appraisal process help employees to get a fair idea of how their efficiency levels or their performance levels are affecting the productivity of the organization as the whole. When an employee understands this it helps them to perform their job duties in the overall company context which tend to positively affect their performance levels since this encourages a sense of team spirit inthem.

\section{Conclusion}

The performance management occupies a strategic importance in an organization since it ensures that the employees of the organization are working in right direction in order to contribute to achieve organizations mission and the objectives. Through the competency framework the leadership and management states the expectations for the employee performance and thus inspire and motivates them to work in right direction to achieve them through the means of performance 
appraisal. Moreover, this competency framework provides the organization with the set process or the benchmark through which they access the performance and potential of the employees and its result on the organizational performance. In the contemporary business environment, people management practices such as performance appraisal and competency framework play a very crucial role in successful management of the organization. Such an effort through human resource management impacts the innovation within the organization moreover it provides organization with the new way of working relationships for maintain work relations. The system of performance appraisal as well as competency framework management is also important for the company to plan, manage and reward the good performance and build talent pipeline for the future. This process further aids the company in improving its productivity and profit levels as well as enables it to manage the complete process of performance supervision by building objectives, checking the feedbacks and evaluating the performances. Moreover, since the employees are the resources for an organization there is need for the firms to figure out the strategies in order to identify employees for future , encourage, measure, evaluate, improve and reward employee work performance for which performance appraisal and competency framework act as an apttool.

7. Limitations and the scope for the futureresearch

Although the present systematic review was well able to evaluate the importance of performance appraisal and competency management framework on the work performance of the employees in telecom sector, but the paper still lagged behind in certain aspects. Like the study is only taking telecom sector in the consideration thus the generalizations made will not be applicable in the other sectors. Moreover, the study is only focused on performance appraisal and competency framework. Other important people management practices such as performance management, compensation and benefit management, Learning and Development, work life balance, Rewards and recognition would have made the study more meaningful, would have increased the scope of the study to evaluate their impact on the employee performance. Further the study can be widened by including other sectors as well in the study.

\section{References}

[1] Aboazoum, H. M. E., Nimran, U. and Musadieq, M. Al (2015) 'Analysis Factors Affecting Employees Job Performance in Libya', IOSR Journal of Business and ManagementVer. I, 17(7), pp. 2319-7668. doi: 10.9790/487X-17714249.

[2] Abram, B. and Anderson, T. (2014) 'Human Resources Professional Competency Framework', p. 139. Available at: https://www.hrpa.ca/Documents/Designati ons/Professional-CompetencyFramework.pdf.

[3] Ademola, S. (2017) 'Impact of Performance Appraisal on Employee Performance in Nigerian Telecommunication Industry ( A study of MTN , Nigeria )', Holistic Approach Journal, 3(1), pp. 80-90.

[4] Aima, P. H., Adam, R. and Ali, P. H. (2017) 'Model of Employee Performance : Competence Analysis and', Journal of Research in Business and Management, 4(11), pp. 49-59.

[5] Arshad, M., Masood, M. and Amin, G. (2013) 'Effects of Performance Appraisal Politics on Job Satisfaction, Turnover Intention and Loyalty to Supervisor.',International Review of Management and Business Research, 2(3), 
pp. 653-673. Available at: http://www.irmbrjournal.com/papers/1379 412617.pdf.

[6] Arshad, U. and Kanwal, U. (2017) 'The influence of organizational culture on training effectiveness', European journal of business and management, 9(10), pp. 197-212. doi: 10.1057/9780230236660_12.

[7] Almusaddar, Ayman AS, Sara RavanRamzan, and ValliappanRaju. "The Influence of Knowledge, Satisfaction, and Motivation on Employee Performance Through Competence." International Journal of Business and General Management (IJBGM) 7.5 (2018): 21-40.

[8] BATTU, NAGARAJU, and SHRIRAM DARBHA. "HOLISTIC EMPLOYEE ENGAGEMENT FOR ACHIEVING PEAK PERFORMANCE AND OVERALL SATISFACTION."

International Journal of

Business and General Management (IJBGM) 6.5, Aug - Sep 2017; 23-32

[9] Benayoune, A. (2017) 'Competency-Based Framework : the Benefits and the Challenges', (9), pp.6-11.

[10] Bulto, L. and Markos, S. (2013) 'Effect of Performance Appraisal System on Employee motivation', Civil Engineering and Construction Review, 21(9), pp. 2536.

[11] Chahal, H., Jyoti, J. and Rani, A. (2016) 'The Effect of Perceived Highperformance Human Resource Practices on Business Performance: Role of Organizational Learning', Global Business Review, 17(May), pp. 107S-132S. doi: 10.1177/0972150916631193.
[12] Chinedu, A. H. et al. (2016) 'Competencies of Mobile Telecommunication Network ( MTN ) Consumers in Competencies of Mobile Telecommunication Network ( MTN ) Consumers in Nigeria Anyanwu Hilary Chinedu a , SharifahAzizahHaron b , Syuhaily Osman c', (December). doi: 10.9790/0837-2111046169.

[13] Clarke, S. and Holdsworth, L. (2017) Flexibility in the Workplace: Implications of flexible work arrangements for individuals, teams and organisations, The International Journal of Human Resource Management. doi: 10.2307/41845205.

[14] Connor, A. M. (2016) 'An Investigation into the Use of Competency Frameworks for Recruitment and Selection in a Financial Services Organisation in Dublin - MA in Human Resource Management National College of Ireland', (August).

[15] Development Dimensions International (2015) 'Competency Management at Its Most Competent Competencies That Work for Business', Development Dimention International, 1(2010), pp. 1-8.

[16] Ehsan, H. (2018) 'Impact of Performance Appraisal, Work Design and Compensation on Employee Performance: A Study of Telecom Sector', Journal of Global Economics, 06(03). doi: 10.4172/2375-4389.1000301.

[17] Ellenkamp, J. J. H. et al. (2016) 'Work Environment-Related Factors in Obtaining and Maintaining Work in a Competitive Employment Setting for Employees with Intellectual Disabilities: A Systematic Review', Journal of Occupational Rehabilitation. Springer US, 26(1), pp. 56-69. doi: 10.1007/s10926-015-9586-1. 
[18] IAEA (2016) 'The Competency

Framework', A guide for IAEA managers and staff 16-06181.

[19] Idowu, A. (2017) 'Effectiveness of Performance Appraisal System and its Effect on Employee Motivation', Nile Journal of Business and Economics, 3(5), p. 15. doi: 10.20321/nilejbe.v3i5.88.

[20] Janjua, B. H. and Gulzar, A. (2014) 'The Impact of Human Resource Practices on Employee Commitment and Employee Retention in Telecom Sector of Pakistan: Exploring the Mediating Role of Employee Loyalty', IOSR Journal of Business and Management, 16(1), pp. 7681. doi: 10.9790/487x-16167681.

[21] Jha, B. and Kumar, A. (2016) 'Employee Engagement: A Strategic Tool to Enhance Performance.',DAWN: Journal for Contemporary Research in Management, 3(2), pp. 21-29.

[22] John (2013) 'Competence management framework for authorities'. doi: $10.2821 / 900656$.

[23] Karen, M. (2013) 'The Importance of Employee Satisfaction with Performance Appraisal Systems'.

[24] Khan, M. A. et al. (2018) 'The Impact of Performance Appraisal on Employee Job Performance in Public Sector Universities of Khyber Pakhtunkhwa, Pakistan', Internasional Journal of Engineering \& Technology, 7(October), pp. 544-548.

[25] KPMG (2014) 'Business success $=\mathrm{f}($ structured competency management )'.

[26] Kurniawan, D. A., Guswandi and Sodikin, A. (2018) 'the Effect of Competence and
Motivation on Employee Performance Through Employees Capabilitieson Pt. Binasinar Amity', International Journal of Research Science \& Management, 5(5), pp. 48-60. doi:10.5281/zenodo.1249804.

[27] Lišková, S. and Tomšík, P. (2013) 'Competency-based approach to human resources management', Agricultural Economics (Czech Republic), 59(11), pp. 496-504. doi: 10.17221/68/2013agricecon.

[28] Mahmood, R. et al. (2018) 'The Mediating Effects of Employee Competency on the Relationship between Training Functions and Employee Performance', International Journal of Academic Research in Business and Social Sciences, 8(7), pp. 664-676. doi: 10.6007/ijarbss/v8-i7/4410.

[29] Malik, K. A., Phil, M. and Bakhtawar, B. (2014) 'Impact of Appraisal System on Employee Performance : a Comparison of Permanent and Contractual Employees of Pakistan Telecommunications Company Limited ( Ptcl )', European Scientific Journal, 1(April 2006), pp. 98-109. doi: 10.1111/j.1523-1739.2004.00023.x.

[30] Malik, M. S. and Aslam, S. (2013) 'Performance Appraisal and Employee' s Motivation: A Comparative Analysis of Telecom Industry of Pakistan', Pakistan Journal of Social Sciences, 33(1), pp. 179189.

[31] Mangundjaya, W., Aprilianti, A. and Poerwadi, N. (2014) 'Developing Employee , s Performance through Competency Assessment', The 2009 International Conference on Human Resource Development, (OCTOBER 2014), pp.115-124.

[32] Martini, I. A. O. et al. (2018) 'The 2529 www.psychologyandeducation.net 
Influence of Competency on Employee Performance through Organizational Commitment Dimension', IOSR Journal of Business and Management (IOSRJBM), 20(2), pp. 29-37. doi:10.9790/487X-2002082937.

[33] Marwat, Z. A., Qureshi, T. M. and Ramay, M. I. M. I. (2013) 'Impact of Human Resource Management (Hrm) Practices on Employees Performance a Case of Pakistani Telecom Sector Impact of Human Resource Management (Hrm) Practices on Employees Performance', International Journal.

[34] Muda, I., Rafiki, A. and Harahap, M. R. (2014) 'Factors Influencing Employees ' Performance: A Study on the Islamic Banks in Islamic Science University of Malaysia University of North Sumatera', International Journal of Business and Social Sience, 5(2), pp. 73-81.

[35] Munisamy, S. (2013) 'Identifying Factors That Influences Job Performance Amongst Employees in Oil Palm Plantation'.

[36] Nadarasa, T. (2013) 'the Impact of Perceived Human Resource Practices on Performance of the Employees Special Reference To the', 2(6), pp. 72-77.

[37] Oshri, I. and Ravishankar, M. N. (2014) 'Industry insight: On the attractiveness of the UK for outsourcing services', Strategic Outsourcing, 7(1), pp. 18-46. doi: 10.1108/SO-11-2013-0022.

[38] Patel, J. (2019) 'RESEARCH PAPER ON BELL CURVE METHOD', 10(1), pp. 3842.

[39] Prowse, P. and Prowse, J. (2009) 'The dilemma of performance appraisal', MeasuringBusiness Excellence, 13(4), pp.
69-77. doi: 10.1108/13683040911006800.

[40] Pulakos, E. D. (2004) 'Performance Management'. Pulakos, E. D. (2012)

'Performance Management'.

[41] Rahmah Ismail and SyahidaZainalAbidin (2010) 'Impact of workers ' competence on their performance in the Malaysian private service sector', Business and Economic Horizons, 2(2), pp. 25-36.

[42] Rost, R. (2014) 'competency model', Praxis Magazin Med., (7-8), pp. 10$12+14+16$.

[43] Saragih, S. (2015) 'The Effects of Job Autonomy on Work Outcomes: Self Efficacy as an Intervening Variable', International Research Journal of Business Studies, 4(3), pp. 203-215. doi: 10.21632/irjbs.4.3.203-215.

[44] Selvarajan, R. and Cloninger, P. A. (2014) 'The importance of accurate performance appraisals for creating ethical organizations', Journal of Applied Business Research, 24(3), pp. 39-44. doi: 10.19030/jabr.v24i3.1340.

[45] Shtern, M. et al. (2015) 'Performance Management and Monitoring', Cloud Services, Networking, and Management, pp. 217-242. doi: 10.1002/9781119042655.ch9.

[46] Singh, Komal, and Akshay Deokar. "Effects of 5S Implementation on Performance of Organization." International Journal of Business and General Management (IJBGM) 7.2 (2018):1-14.

[47] Thao, T. L. T. and Hwang, C. J. (2010) 'Factors Affecting Employee Performance - Evidence FromPetrovietnam 
Engineering', Journal of Management

Research, 21(3), pp. 21-33.

[48] Tripathi, K. and Agrawal, M. (2014)

'Competency Based Management In

Organizational Context: A Literature

Review', Global Journal of Finance and

Management., 6(4), pp. 349-356.

[49] UNESCO (2016) 'UNESCO Competency Framework Learn Develop Excel'. doi: 10.1103/PhysRev.174.429.

[50] Vohra, P. S., and VIPLA CHAUDHARY. "HUMAN RESOURCE ACCOUNTING PRACTICES LEADS

[51] FIRM PERFORMANCE." International Journal of Business and General Management (IJBGM) ISSN (P) (2014):2319-2267.

[52] Yaşar, M. F., Ünal, Ö. F. and Zaim, H. (2013) 'Analyzing the Effects of Individual Competencies on Performance: a Field Study in Services Industries in Turkey', Journal of Global Strategic Management, 2(7), pp. 67-67. doi:10.20460/jgsm.2013715668.

[53] Zafar, M., Karim, E. and Abbas, O. (2017) "Factors of Workplace Environment that Affects Employee Performance in an Organization": A study on Greenwich University of Karachi', Munich Personal RePEc Archive, (April), pp. 1-24.6 